\title{
Land snails on two different sides of Mt. Galunggung
}

\author{
Heryanto Heryanto \\ Research Center for B iology, Indonesian Institute of Sciences, Jalan Raya J akarta B ogor K M 46 Cibinong, Bogor 16911, Indonesia
}

\begin{abstract}
It has been 32 years since the eruption of M ount Galunggung that the land snail diversity in the area were examined, not only in the stricken area but also in the secure place on the other side. The recent collection found 250 snails of 10 families ( 29 species). In the impacted area, 15 species (154 individuals) of land snails were discovered, whereas 18 species (96 individuals) were discovered in the unimpacted area. By a t-Student statistical analysis (95\% confidence interval) for comparison between area of equal variances it was discovered that the two area differ significantly. The analysis was continued by using NMDS of PAST to show the difference more detail. This research proves that the snail assemblage in the impact area of eruption area were different with the snail's assemblage in the unimpacted other side of the Mount.
\end{abstract}

\section{Introduction}

Mt. Galunggung is one of active stratovolcanoes in western Java [1]. The volcano is located at S $7^{\circ} 15^{\prime} 54^{\prime \prime}$ E108 4'3"(https://www.geonames.org/search.html?q=gal unggungcountry=ID). With distances $68.5 \mathrm{~km}$ from Bandung or $155.6 \mathrm{~km}$ from Bogor, the mountain has an altitude of $2,162 \mathrm{~m}$ asl.

Mt. Galunggung erupted in 1982. It attracted the world's attention because the eruption lasted about nine months. The eruption ejected smoke pole around $35 \mathrm{~km}$ high, together with volcanic ash that almost covers the whole West Java. Pyroclastic material flows and causes complete destruction of biota in impacted areas such as south east side of Galunggung. On the other hand, the forest at the western side was only affected by the ashfalls. The environmental catastrophe was predicted to have a major influence on the animal populations especially to small animals which has limited movement like snails.

About three decades after the eruption, together with natural succession, trees of Perhutani replantation grew successfully. The previously most devastated area were flourished by Trema cannabina, Cyathea spp., Villebrunea rubescens, Ostodes paniculata, Macaranga tanarius, Homalanthus populneus, Calliandra calothyrsus, Swietenia mamphylla, Pinus merkusii, and AIbizia fakatatia whereas the floor were occupied by Eupatorium riparicum, Cyathea contaminans, Mikania scandens, Selaginella plana, and Diplazium esculentum [2]. The other side of Mt. Galunggung was dominated by large vegetation such as Schima walichii, Castanopsis argentea, Quercus platycorpa, Vaccinium varingifolium, and Magnolia sp.
Unfortunately, no record has been taken regarding the development of snail life in time series after the eruption to date. As a reflection, a research in West Estonian discover that after 8 years of replantation no snails ever found, 13 years of replantation found 2 species of snails, 25 years of replantation found 9 species of snails [3].

The aim of this work is to describe the current snail assemblage in the area affected by the Mount Galunggung eruption 32 years ago compared to snail assemblage in an area where the impact of the eruption was very small or not affected at all.

\section{Material and Methods}

\subsection{Sampling Work}

Snails sampling for eruption impacted area were conducted in the horseshoe shaped of Mt. Galunggung. On the other hand, snails sampling for the nonimpacted area was conducted in an area close to Talaga Putih crater. Sampling was carried out using the purposive method by tracing the land snails' habitat in the study area. The land snail habitats such as herbaceous vegetation, mosses, litter and the upper soil layer were disclosed to find the land snails existence. The sampling work covered 4 sites in each area with $33.33 \times 33.33 \mathrm{~cm}^{2}$ frames were spread out as sampling plot in each site. Eleven frames were set up in unimpacted areas and 21 frames in impacted areas. The snails found in the frame were put in plastic containers to prevent it from damage. Photograph of a snail while still alive was taken. Living snails were collected and killed by immersing them in fresh water for 12 hours. Dead snails were preserved in

* Corresponding author: heryantomzb@yahoo.com 
$70 \%$ alcohol solution and stored in vials and labelled. All samples were deposited at the Malacology Laboratory, Bogor Zoological Museum in Cibinong, Bogor.

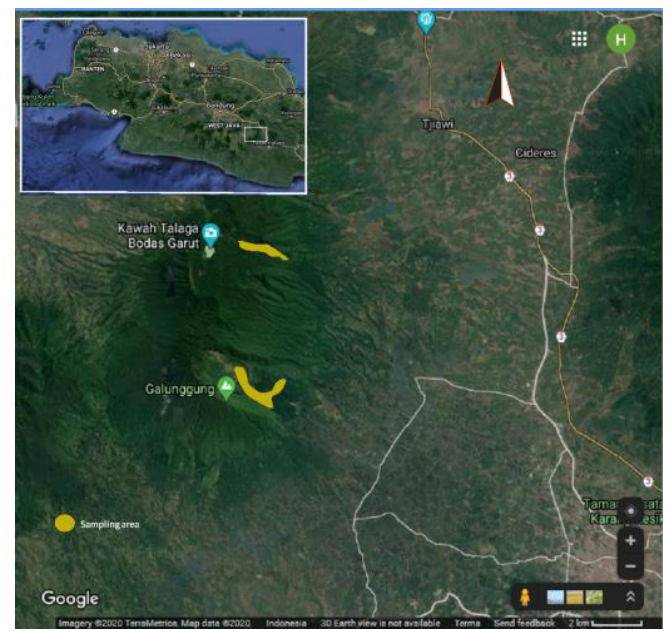

Fig. 1. Sampling areas in both sides of M t. Galunggung (B asic maps by Google)

\subsection{Laboratory Work}

In the laboratory, samples were sorted based on character similarity and counted. All samples, both large and small, were washed individually from all mud and other impurities. Dirty micro-size samples were cleaned in loose vial by using the Sibata ultrasonic cleaner for 3 hours. Clean samples were put into new preservation containers with new preservation and new label. Samples identification referred to van Benthem-Jutting [4-6].

\subsection{Statistical Analysis}

The mollusc samples subjected to analyses were based on live and shell individuals. Statistical analyses of comparing two areas were performed using Student's ttest between two groups of Excel 2010 and strengthen by ordination technique of Non-Metric Multidimensional Scaling (NMDS), with the Bray-Curtis similarity index. This last analysis used the software PAST 2.10.

\section{Results and Discussion}

Land snail sampling yielded 250 individual snails, representing 10 families, 14 genera, and 29 species (Table 1). It has been found that snails' abundance in impacted area is higher than that of in unimpacted area. As many as 154 individuals of snail samples were from impacted area whereas from 96 individuals of snail samples were from unimpacted area.

The snail is very prone to volcanic eruptions since it cannot move fast and escape quickly. In addition, the environment around the eruption site is also not immediately inhabitable because the environment is not in accordance with the needs of snail life. For example, snail needs habitat with low temperature and high humidity which will not be found in the place where the volcanic eruption affected. The hot environment turned off the vegetation in the impacted area and generate no leaf litter left for snails to be eaten. Furthermore, the desolate area when stricken by heavy raindrops as often occurs in a mountain area leads to erosion [7].

Statistical analysis of t-Student $(95 \%$ confidence interval) for comparison between area of unequal variances revealed that the two area were differ very significantly. The t-test convincingly that both group of snails were truly different, not only the location where they live, but also species assemblage.t is attest that volcano eruption does not only change the physical area but all life in the area including snails and the process thereafter.

In accordance with Student-t test, the non-metric multidimensional scaling of PAST program discloses two groups of different sites. In Figure 2, four blue dots represent sites in impacted areas whereas four red dots represent sites in unimpacted areas. The neighbouring blue dots indicate similarity between them, at least live in the same location.

It is doubtless that the Galunggung eruption destroy snail' habitat including the snails inside. After passing through 3 decades, succession is still going on. The impacted area now colonized by pioneer species and other plant species [8]. When the trees growth become large, and shed their leaves, the litter established on the forest floor. Gradually the forest succession was occupied by snails. The snails found in the area may come from surviving snail in refuge surround, similar to the snails in burnt area [9]. More snail species were probably dispersed from surrounding area of Galunggung where not impacted by the eruption and established the communities. Probably they were introduced by human in a way stick to plant for reforestation. The thickness of leaf litter accelerated the species richness since they were in association [10]. As stated by Magnin et al. [11] and Kiss \& Magnin [12] that vegetation regulates the gastropods in term of food, shelter, and close ground climate. Since this successive environment was suitable for the snails, they were developed quickly, and hence created the abundance higher than the snails in the unimpacted area. Snail species often found in shrubs such as Japonia convexum and Japonia. grandipilum were occur in a large amount in the area as the large trees were not arise yet.

On the contrary, the evenness in the impacted areas is smaller than that of in the unimpacted area, revealed 15 species in the impacted areas in comparison with 18 species in the unimpacted areas (Tabel 1). It can be understood since the snail existence in the unimpacted area was not interrupted by such disaster as Galunggung eruption. Alteration of the habitat change the snails rapidly [13]. Snails in the impacted area must start a new life. Only species which able to adapt to the new environment that can live on. For example, after affliction of burned in Mediterranean forest area, the land snail communities' successor appears to be different composition from previous occupant. The new occupant mostly xerophilous species $[14,15]$. On the other hand, the snail which live in an unimpacted area continues its life cycle like its ancestors. 
Table 1. The snails' abundace and evenness in impacted and unimpacted areas of Mount Galunggung eruption

Abundace and evenness

\begin{tabular}{|c|c|c|c|}
\hline & & Impacted area & Unimpacted \\
\hline I & Cyclophoriidae & & \\
\hline 1 & Cyclophorus perdix perdix (Broderip \& Sowerby,1829) & & 1 \\
\hline 2 & Japonia ciliocinctum (Martens 1865) & & 2 \\
\hline 3 & Japonia convexum Moellendorff 1897 & 73 & 1 \\
\hline 4 & Japonia grandipilum Boettger 1891 & 12 & \\
\hline II & Pupinidae & & \\
\hline 5 & Pupina bipalatalis Boettger 1890 & & 1 \\
\hline 6 & Pupina compacta Moellendorff 1897 & & 1 \\
\hline III & Diplommatinidae & & \\
\hline 7 & Diplommatina auriculata var. abbreviata Moellendorff 1897 & 1 & 3 \\
\hline 8 & Diplommatina calcarata Moellendorff 1897 & & 12 \\
\hline 9 & Diplommatina cyclostoma Moellendorff 1897 & & 1 \\
\hline 10 & Diplommatina baliana Fulton 1899 & 21 & \\
\hline 11 & Diplommatina sp. & & 17 \\
\hline IV & Helicarionidae & & \\
\hline 12 & Helicarion perfragilis (Moellendorff 1897) & 5 & \\
\hline V & Euconulidae & & \\
\hline 13 & Liardetia amblia (Moellendorff 1897) & & 4 \\
\hline 14 & Liardetia convexoconica (Moellendorff 1897) & 7 & \\
\hline 15 & Liardetia dendrophila van Benthem Jutting 1950 & 2 & \\
\hline 16 & Liardetia platyconus Moellendorff 1897 & 1 & \\
\hline 17 & Liardetia reticulata Benthem Jutting 1950 & & 4 \\
\hline VI & Chronidae & & \\
\hline 18 & Kaliella barrakporensis (Pfeiffer 1852) & 2 & \\
\hline VII & Ariophantidae & & \\
\hline 19 & Microcystina subglobosa (Moellendorff 1897) & & 1 \\
\hline 20 & Microcystina vitreiformis (Möllendorff 1897) & & 11 \\
\hline 21 & Microcystina gratilla Benthem Jutting 1950 & 1 & \\
\hline 22 & Landouria cf leucochila (Gude 1905) & 8 & \\
\hline 23 & Landouria sp. & 17 & 3 \\
\hline 24 & Chloritis fruhstorferi Moulendorff 1897 & 1 & 1 \\
\hline VIII & Dyakiidae & & \\
\hline 25 & Dyakia clypeus (Mousson 1842) & & 2 \\
\hline IX & Ellobiidae & & \\
\hline 26 & Carychium javanum Moellendorff 1897 & & 30 \\
\hline $\mathrm{X}$ & Achatinidae & & \\
\hline 27 & Allopeas clavulinum (Potiez \& Michaud 1838) & & 1 \\
\hline & Allopeas gracile (Hutton 1834) & 1 & \\
\hline \multirow[t]{3}{*}{29} & Prosopeas acutissimum (Mousson 1857) & 2 & \\
\hline & Evenness & 15 & 18 \\
\hline & Abundance & 154 & 96 \\
\hline
\end{tabular}


Table 2. The output of Excel's data analysis

\begin{tabular}{lrr}
\multicolumn{3}{c}{ t-Test: Two-Sample Assuming Unequal Variances } \\
\hline Mean & 1 & \multicolumn{1}{c}{2} \\
Variance & 5,3103448 & 3,3103448 \\
Observations & 197,86453 & 42,935961 \\
Hypothesized Mean Difference & 29 & 29 \\
df & 0 & \\
t Stat & 40 & \\
P(T<=t) one-tail & 0,6940653 & \\
t Critical one-tail & 0,2458264 & \\
P(T<=t) two-tail & 1,683851 & \\
t Critical two-tail & 0,4916528 \\
& 2,0210754 \\
\end{tabular}

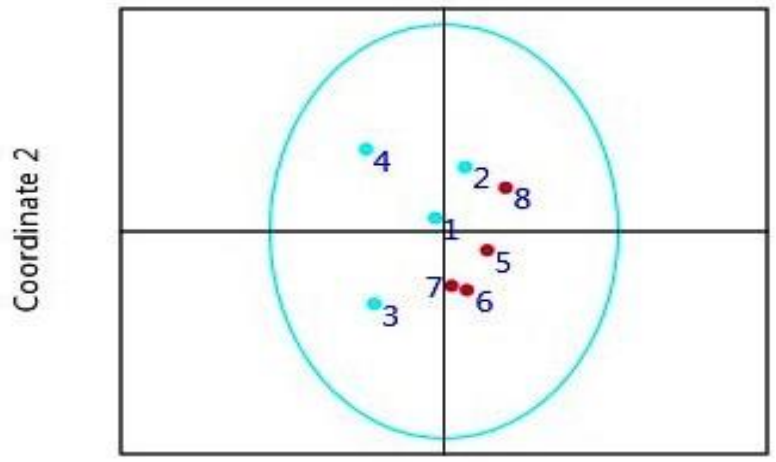

Coordinate 1

Fig. 2. Non-metric multidimensional scaling for the 2 groups (in impacted and unimpacted areas) of 8 land snail sites.

The large species such as C. perdix perdix and D.clypeus were live in unimpacted area where shrubbery and litter occur thickly together with the litter dweller $D$. auriculata, Diplommatina sp. and M. vitreiformis. The micro sized shrubbery snail of $C$. javanum lives on underbrush close to forest floor. Snails which preference habitat is the moistest, Pupina spp, were also develop in this area.

\section{Conclusion}

The eruption of Mount Galunggung in the past 32 years has changed the assemblage of snails into new ones which are mostly bush dwellers and thin litter floor. The snails that best suit their environment are present in large numbers

The research in Mount Galunggung was financed by the Research Center for Biology-LIPI through the Program of DIPA 2013 - 2014. I thanked Alfiah for collecting the snails in Mount Galunggung (2013) and Talaga Bodas (2014) and Riena Prihandini for specimens' preparation (Laboratory of Malacology, Museum Zoology Bogor, Research Center for Biology- LIPI)

\section{References}

1. R. A'sari, D. Maryani, E. Ningrum, Identification of Galunggung volcano potential area for geographic education field laboratory development (IOP Conference Series, Tanjung Maling, 2019). doi:10.1088/1755-1315/286/1/012011
2. A. Sutanto, Suksesi vegetasi jenis pohon dan tumbuhan bawah pasca letusan Gunung Galunggung (Studi kasus di BKPH Tasikmalaya, KPH Tasikmalaya PT. (Persero) Perhutani Unit III Jawa Barat) (Skripsi IPB, 2002).

3. R. Mänd, A. Ehlvest, P. Kiristaja, Proceedings of the Estonian Academy of Sciences, Biology and Ecology, 50, 37-41, (2001).

4. W.S.S. van B enthem Jutting, Treubia, 19, 539-604 (1948).

5. W.S.S. van B enthem Jutting, Treubia, 20, 381-505 (1950).

6. W.S.S. van B enthem Jutting, Treubia, 21, 291-435 (1952).

7. L. Jost, Oikos 113 (2), 363-375 (2006). https://doi.org/10.1111/j.2006.0030-1299.14714.x

8. M. Zuhri, H. Wiriadinata, R. S. Astuti, S. Hadiwaluyo, Syamsudin. J. Trop. Life Sci.e, 6(2), 69-78, (2016). doi: $10.11594 /$ jtls. 06.02 .02

9. E.J. Ray, E.A. Bergey, J. Molluscan Stud. 81, 4450, (2015). doi:10.1093/mollus/eyu051

10. T. Wronski, K. Gilbert, E. Long, B. Michá, R. Quinn, B. Hausdorf, J. Molluscan Stud. 80(2), 161168, (2014). doi:10.1093/mollus/eyu008

11. F. Magnin, T. Tatoni, P. Roche, J. Baudry, Landsc. Urban Plan. 31, 249-257 (1995). https://doi.org/10.1016/0169-2046(94)01049-E

12. L. Kiss, F. Magnin, J. Molluscan Stud. 69, 43-53 (2003). DOI: 10.1093/mollus/69.1.43

13. G. Coppois, Bull. inst. r. sc. nat. belg. 70, 27-29 (2000)

14. L. Kiss, F. Magnin, F. Torre, J. Biogeogr. 31, 145157 (2004). https://doi.org/10.1046/j.03050270.2003.01011.x

15. X. Santos, V. Bros, E. Ros, Contrib. Zool. 81, 167 -180 (2012). 